\title{
A CHECKLIST OF PTEROMALIDAE (HYMENOPTERA: CHALCIDOIDEA) FROM THE INDIAN SUBCONTINENT
}

\author{
P.M. Sureshan ${ }^{1 *}$ and T.C. Narendran ${ }^{2}$ \\ ${ }^{1}$ Zoological Survey of India, Western Ghats Field Research Station, Kozhikode, Kerala 673002, India. \\ ${ }^{2}$ Systematic Entomology Laboratory, Department of Zoology, University of Calicut, Tengipalam, Kerala, 673635, India. \\ Email: ${ }^{1}$ zsipune@mah.nic.in; ${ }^{2}$ drtcnarendran@yahoo.com
}

\begin{abstract}
A checklist of the genera and species of Pteromalidae (Hymenoptera: Chalcidoidea) so far reported from the Indian subcontinent is provided. Of the 96 genera, 84 with 185 identified species and 12 genera with unidentified species are listed.
\end{abstract}

\section{Keywords}

Chalcidoidea, checklist, distribution, habitat, host data, hymenoptera, Indian Subcontinent, locality, pteromalidae, synonymy,

\section{Introduction}

The Pteromalidae is one of the largest and difficult families of Chalcidoidea (Hymenoptera) to define taxonomically and phenetically. The family is distributed in all biogeographical areas of the world and shows great diversity in morphology and biology. The great majority of Pteromalidae are primary or secondary parasitoids attacking a large number of insects in their various stages of development. A few pteromalids are phytophagous. Some of them develop in seeds of plants, others are gall makers and still others develop as inquilines in galls caused by other insects. They play an important role in the biological control of serious insect pests in the field and many of them are employed successfully in biological control programmes all over the world.

Pteromalidae contains over 3400 described species under 587 genera worldwide (Noyes, 2001). Though there were several scattered publications on the Pteromalidae of the Indian subcontinent, it was Boucek et al. (1979) who provided a more complete picture of the fauna of the region. According to Boucek et al. (1979) the pteromalid fauna of the Indian subcontient is known by 112 species under 80 genera. Farooqi and Subba Rao $(1985,1986)$ keyed out and catalogued the pteromalid genera and species known from the region. In recent years, several new genera and species of Pteromalidae have been described from the forested tracts of southern Western Ghats, a biodiversity hotspot centre in India (Sureshan, 1999a,b; 2000a,b; 2001a,b,c; Sureshan \& Narendran, 1995a,b; 1998; Narendran \& Mini, 1999, etc.) and from other regions in India. Accordingly an updated checklist of the pteromalid fauna of the Indian subcontinent is presented here. It includes altogether 96 genera, 84 of them with 185 identified species and 12 genera with unidentified species. In the present work, the classification of the family given by Boucek (1988) is followed.

\section{Arrangement of the checklist}

In the checklist, pteromalid genera known so far from the Indian subcontinent are grouped under separate subfamilies. The subfamilial classification by Boucek (1988) is followed. Under each subfamily the genera are listed in alphabetical order. Name of the genus is followed by the author and year. Under each genus, species are listed in alphabetical order. Name of the species is followed by the author and year, which is followed by its distribution in the Indian subcontinent. In the distribution, name of the country is followed by the state, available localities, type of the habitat and host data available from the region. The distribution of the species in other parts of the world is given in brackets. The genera endemic to India are marked with asterisks.

\section{Discussion}

The present checklist deals with 185 species pertaining to 96 genera and 16 subfamilies of Pteromalidae known so far from the Indian subcontinent. Out of the genera reported from the region eight are endemic to India. Geographically, the checklist covers the so-called Indian subcontinent including Pakistan, India, Nepal, Bangladesh, Bhutan, Myanmar and Sri Lanka. When compared to the other geographical regions of the world,

* Present address: Zoological Survey of India, Western Regional Station, Vidhya Nagar, Sector 29, Rawet Road, Pune, Maharashtra 411044, India.

Received 15 June 2002; $\quad$ Revised received 29 January 2003; $\quad$ Finally accepted 25 March 2003 
studies on the Pteromalidae of the Indian subcontinent is still in an infantile stage. The European fauna have been studied in detail by Graham (1969). The best work for the Australasian region is by Boucek (1988). Boucek and Heydon (1997) provided a key to the Nearctic fauna. Studies of Boucek et al. (1979), Farooqi and Subba Rao $(1985,1986)$ and Sureshan (2003a) provided a more comprehensive picture of pteromalid fauna of the Indian subcontinent, which is not isolated in the world. Many Palearctic genera and species are known from the Indian subcontinent apart from several Ethiopian and Australian elements. Several genera and species of Pteromalidae have become cosmopolitan in distribution due to their introduction in different parts of the world mainly with various crops and as bicontrol agents. Since many new taxa of Pteromalidae are being described from the region, the checklist has to be updated periodically.

\section{Acknowledgements}

The first author is grateful to the Director, Zoological Survey of India, Kolkata and the Officer-in-charge, Zoological Survey of India, Western Ghats Field Research Station, Kozhikode and Zoological Survey of India, Western Regional Station, Pune for providing facilities and constant encouragement.

\section{References}

Ahmad, M.J. (1995). A new species of Gastrancistrus Westwood (Chalcidoidea: Pteromalidae) from India. Shashpa 2(2): 95-96.

Ahmad, M.J. (1997). A new species of Merismus Walker (Chalcidoidea: Pteromalidae) from Nainital Hills. Shashpa 4(1): 1315.

Ahmad, M.J. (1998). One new species and two new records of Spalangia Latr. (Chalcidoidea: Pteromalidae) from India. Shashpa 5(1): 9-12.

Ahmad, M.J. and M.M. Agarwal (1994). First record of Trigonoderopsis Girault (Chalcidoidea) with a new species from India. Shashpa 1(2): 5-6.

Ahmad, M.J. and M.M. Agarwal (1994). A new species of Merismomorpha Girault (Chalcidoidea: Pteromalidae) from North India. Journal of Entomological Research 18(3): 229-232.

Ahmad, T. (1939). The Amaranthus borer Lexus truncatulus (F.) and its parasites. Indian Journal of Agricultural Science 9: 609-627.

Ahmad, T. and M.S. Mani (1939). Two new Chalcidoid parasites of the linseed midge Dasyneura lini Barnes. Indian Journal of Agricultural Science 9: 531-539.

Ashmead, M.J. (1887). Studies on the North American Chalcididae with descriptions of new species chiefly from Florida. Transactions of the American Entomological Society 14: 183-203.

Ashmead, M.J. (1894). Descriptions of new Parasitic Hymenoptera. Transactions of the American Entomological Society 21: 318-344.

Ashmead, M.J. (1904). Classification of the Chalcid flies or the superfamily Chalcidoidea with descriptions of new species in the Carnegie Museum. Memoirs of the Carnegie Museum. 1(4): 225-551. Boucek, Z. (1954). Chalcidologicke poznamky I. Pteromalidae, Torymidae, Eurytomidae, Chalcididae (Hymenoptera). Acta Fauna Entomologica Musei Nationalis Pragae 29: 49-80.

Boucek, Z. (1963). A taxonomic study in Spalangia Latr.
(Hymenoptera: Chalcidoidea) Acta Fauna Entomologica Musei Nationalis Pragae 35: 429-512.

Boucek, Z. (1965). A review of the Chalcidoid fauna of the Moldavian S.S.R with descriptions of new species (Hymenoptera) Acta Fauna Entomologica Musei Nationalis Pragae 11: 5-37.

Boucek, Z. (1973). An interesting new genus of Pteromalidae (Hymenoptera) with evaniform gaster. Oriental Insects 7: 557-561.

Boucek, Z. (1976). African Pteromalidae (Hymenoptera). New taxa, synonymies and combinations. Journal of the Entomological Society of Southern Africa 39: 9-31.

Boucek, Z. (1978). Oricoruna and Manineura, new Pteromalid genera (Hymenoptera) from the Oriental Region. Oriental Insects 12(4): 469-472.

Boucek, Z. (1986). Taxonomic study of Chalcidoid wasps (Hymenoptera) associated with gall midges (Diptera: Cecidomyiidae) on mango trees. Bulletin of Entomological. Research. 76: 393-407.

Boucek, Z. (1988). Australasian Chalcidoidea (Hymenoptera) - A biosystematic revision of genera of fourteen families with the reclassification of species. Wallingford, U.K. CABI. 832.pp.

Boucek, Z. and S.L. Heydon (1997). Family Pteromalidae pp. 541692. In: Gibson, G.A.P., J.T. Huber and J.B. Wooley (editors). Annotated keys o the genera of Nearctic Chalcidoidea (Hymenoptera). NRC Research Press Ottawa, Ontario, Canada, 704pp.

Boucek, Z., S.B.R. Rao and S.I. Farooqi (1979). A preliminary review of Pteromalidae (Hymenoptera) of India and adjacent countries. Oriental Insects 121(4): 433-467.

Bouche, P.F. (1834). Naturgeschichte der Inseckten, besonders in Hinsicht ihrer ersten Zustaende als Larven und Puppen $\mathrm{v}+216 \mathrm{pp}+10 \mathrm{pls}$. Berlin.

Bukowski, W. (1938). Neue und wenig bekannte Chalcididen (Hymenoptera) I. Entomologicheskoe Obozvenie 27: 152-171.

Burks, B.D. (1959). The species of the genus Herbertia Howard (Hymenoptera: Pteromalidae). Proceedings of the Entomological Society of Washington 61: 249-255.

Cameron, P. (1883). Descriptions of new genera and species of Hymenoptera. Transactions of the Entomological Society of London 187-197.

Cameron, P. (1903). Descriptions of new genera and species of Hymenoptera taken by Mr. Robert Shellford at Sarawak, Borneo. Journal of Straits Branch of Royal Asiatic Society 39: 89-181.

Cameron, P. (1906). On the Tenthredinidae and parasitic Hymenoptera collected in Baluchistan by Major C.G. Nurse. Journal of the Bombay Natural History Society 17: 89-107.

Crawford, J.C. (1909). New Chalcidoidea (Hymenoptera). Proceedings of the Entomological Society of Washington 11: 51-52.

Crawford, J.C. (1911). Descriptions of new Hymenoptera No.3. Proceedings of the United States National Museum 41: 267-282.

Crawford, J.C. (1913). Descriptions of new hymenoptera No.6. Proceedings of the United States National Museum 45: 241-260.

Curtis, J. (1839). British Entomology 16: folios 722-769, London.

Delucchi, V. (1956). Beitrage zur Kenntnis der Pteromaliden (Hymenoptera. Chalcidoidea). Zeitschrift feur Angewandte Entomologie 39: 229-257.

Delucchi, V. (1962). Hymenoptera Chalcidoidea in Resultats guentifiquesde missios zoologiques de I.I.R.S.A.C. en Afrique.

Dutt, N. and C. Ferriere (1961). On the chalcidoid parasites of the jute stem girdler from West Bengal. Indian Journal of Agricultural Science 31: 139-142.

Fabricius, I.C. (1787). Mantissa Insectorum sistens eorum species 
nuper detectas adiectis characteribus generias differentitis specificis, emendationibus, observationibus 20+348pp.

Farooqi, S.I. (1980). Descriptions of a new species of Cephaleta hayati (Hymenopptera: Pteromalidae) parasitc on Cerococcus sp. in India. Journal of Entomological Research 4(2): 119-122.

Farooqi, S.I. (1983). A contribution to the knowledge of Indian Eunotinae (Pteromalidae: Chalcidoidea). Journal of Entomoligical Research.7(2): 184-189.

Farooqi, S.I. and M.G.R. Menon (1972). A new phytophagous species of Systasis Walker (Hymenoptera: Pteromalidae) infesting seeds of Cenchrus species. Mushi 46: 111-114.

Farooqi, S.I. and B.R. Subba Rao (1985). Family Pteromalidae pp. 256-263. In: B.R. Subba Rao and M. Hayat (Editors) the Chalcidoidea (Insecta: Hymenoptera) of India and the adjacent countries - Part I. Review of families and keys to families and genera. Oriental Insects 19: 161-310; 15.

Farooqi, S.I. and B.R. Subba Rao (1986). Family Pteromalidae pp. 279-306. In: B.R. Subba Rao and M. Hayat (Editors) the Chalcidoidea (Insecta: Hymenoptera) of India and the adjacent countries - Part II. A catalogue. Oriental Insects 20: 1-430.

Ferriere, C. (1930). Notes on Asiatic Chalcidoidea. Bulletin of Entomological Research 21: 353-360.

Ferriere, C. (1931a). Notes on African Chalcidioidea. Bulletin of Entomological Research 22: 127-135.

Ferriere, C. (1931b). New Chalcidoid egg-parsites from south Asia. Bulletin of Entomological Research 22: 279-295.

Ferriere, C. (1934). Note sur les Pireninae, avec descriptions de deux nouvelles especes. Mitteulungen der Schweizerischen Entomologischen Gesellschaft 16: 83-93.

Ferriere, C. (1939). Chalcid flies attacking noxious beetles in India and New Guinea. Bulletin of Entomological Research 33: 163-168.

Forster, A. (1841). Beitrage zur Monographieder Pteromalinen Nees 1: $47 \mathrm{pp}+1 \mathrm{pl}$.

Forster, A. (1856). Hymenopterologische Studien 2. Heft. Chalcidiae und Proctotupii. 152pp. Aachen.

Gahan,A.B. (1919). Report on a small collection of Indian parasitic Hymenoptera. Proceedings of the United States National Museum 56: 513-524+pl.1.

Gahan, A.B. (1925). A second lot of parasitic Hymenoptera from the Philippines. Philippine Journal of Science 27: 83-111.

Girault, A.A. (1913a). Australian Hymenoptera Chalcidoidea VI. The Family Pteromalidae with descriptions of new genera and species Memoirs of the Queensland Museum 2: 303-334.

Girault, A.A. (1913b). New genera and species of Chalcidoid Hymenoptera in South Australian Museum. Transactions of the Royal Society of Australia 37: 67-115.

Girault, A.A. (1915a). Australian Hymenoptera Chalcidoidea VI -supplement. Memoirs of the Queensland Museum 3: 313-346.

Girault, A.A. (1915b). Australian Hymenoptera Chalcidoidea VII. Memoirs of the Queensland Museum 4: 1-184.

Girault, A.A. (1915c). Australian Hymenoptera Chalcidoidea VIII. The family Miscogasteridae with descriptions of new genera and species. Memoirs of the Queensland Museum 4: 185-202.

Girault, A.A. (1915d). Australian Hymenoptera Chalcidoidea IX. The family Cleonymidae with descriptions of new genera and species. Memoirs of the Queensland Museum 4: 203-224.

Girault, A.A. (1915e). Some chalcidoid hymenoptera from North Queensland. Canadian Entomologist 47: 42-48.

Girault, A.A. (1936). Chalcidiae capsidae species nova Australiensis
Giraulti 2pp. (Girault: Brisbane).

Girault, A.A. (1938). some new Australian insects which are parasites (Hymenoptera: Chalcidoidea). Revista De Entomolgia Rio de Jenero 8: 80-89.

Girault, A.A. (1939). A new genera and species of Australian Pteromalidae. North Queensland Natuaralist. 7(58): 2.

Graham, M.W.R. de V. (1956a). A revison of the Walker types of Pteromalidae (Hymenoptera: Chalcidoidea) part I including descriptions of new genera and species. Entomologist's Monthly Magazine 92: 76-98.

Graham, M.W.R.de V. (1956b). A revision of the Walker types of Pteromalidae (Hymenoptera: Chalcidoidea) part 2 (including descriptions of new genera and species). Entomologist's Monthly Magazine 92: 246-263.

Graham, M.W.R. de V. (1969). The Pteromalidae of North-Western Europe (Hymenoptera: Chalcidoidea). Bulletin of British Museum of Natural History Entomology supplement 16: 1-908.

Graham, M.W.R.deV. and M.F. Claridge (1965). Studies on the Stenomalina group of Pteromalidae (Hymenoptera: Chalcidoidea). Transactions of the Royal Entomological Society 117: 262-311.

Hartig, T. (1838). Uber des Rampenfrass in koniglichen charlottenburger Forste unfern Berlin, Wahrenddes Sommers 1837. Jahresberichte uber die Fortschritte der Forstwissenschaft und Forstlichen Naturkundede im Jahre-1836 und 1837 nebst OriginalAbhendlungen aus dem Gebiete und Cameralistenl 1: 246-274.

Hedqvist, K.J. (1969). Notes on Cerocephalini with descriptions of new genera and species (Hymenoptera: Chalcidoidea: Pteromalidae). Proceedings of the entomological Society of Washington 71. 449-467. Holmgren, A.E. (1872). Insectrer fran Nordgronland, samlade af Prof. A.E.Nordenskiold ar 1870. Ofversigt Af $k$ vetenskaps akademiens forhandlinger. 29: 97-105.

Howard, L.O. in J.H. Comstock (1881). Report of the Entomologist. for 1880. United States Department of Agricultural Entomology 1880: i-iv, 235-373. IU.V, 24pls.

Howard, L.O. (1894). In: Riley, Ashmead and Howard. Report on the Chalcidoidea of the subfamilies Chalcidinae, Eucharinae, Perilampinae, Encyrtinae, Aphelinae, Pireninae, Elasminae and Elachistinae. Journal of Linnean Society London 25: 79-108. (in 56254.)

Howard, L.O. (1896). On two interesting new genera of scale insect parasites. Canadain Entomologist 28: 165-167.

Kamijo, K. and E.E. Grissell (1982). Species of Trichomalopsis Crawford (Hymenoptera: Pteromalidae) from rice paddy with descriptions of new species. Kontyu 50: 76-87.

Latreille, P.A. (1805). Genera Crustaceorum et Insectorum 4. 399 pp. Paris \& Strasbourg.

Latreille, P.A. (1809). Genera Crustaceorum et Insectorum Secundum ordinem naturalem, in familie disposita iconibus, exemplisque plurimis explicata $4 ; 399$.

Linnaeus, C. (1758). Systema Naturae (10 ${ }^{\text {th }}$ Edition). 1: 824+iiipp. Stockholm.

Mani, M.S. (1939). Descriptions of new and records of some known Chalcioid and other hymenopterous parasites from India. Indian Journal of Entomology 1: 69-99.

Mani, M.S. (1942). Studies on Indian parastic Hymenoptera II. Indian Journal of Entomology 4: 153-162.

Mani, M.S. and K. Chandy (1953). Descriptions and records of chalcids (parastic Hymenoptera) from India. Indian Journal of Entomology 15: 1-21. 
Mani, M.S., O.P. Dubey, B.K. Kaul and G.G. Saraswat (1973). On some Chalcidoidea form India. Memoirs of the School of Entomology, St. John's College, Agra 2: 1-128.

Mani, M.S., O.P. Dubey, B.K. Kaul and G.G. Saraswat (1974). Descriptions of some new and records of some known Chalcidoidea (Hymenoptera) from India. Memoirs of the School of Entomology, St. John's College, Agra 3: 1-108.

Masi, L.(1911). Contribuzioni alla conoscenza dei chalcididi italiani (Part.IV). Bolletino del laboratorio di zoologia generale E Agraria Della R scuola superiore d agricoltura in Portici 5: 205-208, 1fig.

Masi, L. (1917). Chalcidiae of the seychelles islands. Novitates Zoologicae 24: 121-230.

Masi, L. (1924a). Calcididi del Giglio Quarta Serie Pteromalinae (seguito) Annali del Museo Civico di Storia Naturale Giacomo Doria 50: 213-235.

Masi, L. (1924b). Note sui generi Bruchobius, Oedaule Sphaerakis con descrizione di nuove specie (Hymenoptera: Chalcididae). Annali del Museo Civico di Storia Naturale Giacomo Doria 51: 149-160.

Masi, L. (1927). Note sul genere Picroscytus Thoms. con diagnosi dinuove specie (Hymenoptera. Chalididae). Annali del Museo Civico di Storia Naturale Giacomo Doria 52: 318-823.

Masi, L. (1929). Risultati zoologicidella Missione inviata della R. Siocieta Geographica Italiana per L esplorazione dell Oasi di Giarabub ( 1926-1927) Hymenoptera, Chalcididae. Annali del Museo Civico di Storia Naturale Giacomo Doria 53: 195-240.

Mokrzecki, Z. (1933). Bleskotki (Chalcidoidea) zyjace jako pasorzytyI III. Stopnia na szkodnikach lesnych Die in den Fortschadlingen lebebdeb parasiten des i.und 2. Grades aus der Gruppe der V (Chalcidoidea) polskie pismo ent 12: 143-144.

Motschulsky, V. De. (1859). Insectes utiles et lunisibles. Etudes entomologiques 8: 87pp., Helsingfors.

Motschulsky, V.De. (1863). Essai d un catalogue des Insects de 11 le ceylan. Bulletin de la societe imperiale des naturalists de Moscou 36(2): 1-153.

Narendran, T.C. (1992). A new species of Riekisura Boucek (Hymenoptera: Pteromalidae) from India. Journal of Advanced Zoology 13(1\&2): 57-58.

Narendran, T.C. (2000). A key to species of Grahamisia Delucchi (Hymenoptera: Pteromalidae: Diparinae) with description of a new species from India. Zoos'Print Journal 15(12): 371-374.

Narendran,T.C. (2001). A new record of the genus Erotolepsiella Girault (Hymenoptera:Pteromalidae) from the Oriental Region with description of a new species from India. Zoo's Print Journal 16(2): 418-420.

Narendran, T.C. and T.V. Mini (1999). A review of the genera of Oriental Eunotinae (Hymenoptera: Pteromalidae). Journal of the Zoological Society of Kerala 8 \& 9: 15-28.

Narendran,T.C. and B.K. Das (2000). A new species of the rare genus Austroterobia Girault (Hymenoptera: Pteromalidae: Austroterobinae) from West Bengal, India. Zoo's Print Journal 15(9): 319-321.

Narendran, T.C. and P.M. Sureshan (2001). Descriptions of three new species of Dipara Walker (Hymenoptera: Pteromalidae) from India. Zoo's Print Journal 16(4): 451-456.

Narendran, T.C., K. Anil and K. Surekha (1992a). On some important and beneficial Chalcids (Hymenoptera: Chalcidoidea) associated with sericulture industry in India. Bioved 3(1): 1-6.

Narendran, T.C., K. Anil and K. Chandrasekharan (1992b). A new species and a new record of the remarkable genus Delislea Girault
(Hymenoptera: Pteromalidae) from the Oriental Region. Journal of the Bombay Natural History Society 89: 231-233.

Narendran, T.C., T.V. Mini and K.A. Karmaly (2000). A new species of Parurios Girault (Hymenoptera: Pteromalidae: Diparinae) from Kerala (India). Bulletin of Pure and Applied Sciences 194(2): 137140.

Narendran, T.C., A.A. Buhroo and M.Z. Chisti (2001a). Taxonomic studies on four new species of Chalcidoidea (Hymenoptrea) of economic importance from Kashmir, India. Entomon 26(2): 147-159. Narendran, T.C., B.K. Das and K. Rajmohana (2001b). A study of Gastrancistrus Westwood (Hymenoptera: Pteromalidae) of India. Journal of Ecobiology 13(2): 149-155.

Narendran, T.C., K. Rajmohana and T. Jobiraj (2001c). Three new species of Pteromalidae (Hymenoptera) from Kerala (India). Uttar Pradesh Journal of Zoology 21(1): 27-34.

Nees E.C.G. (1834). Hymenopterorum Ichneumonibus affinium monographia genera, eropaes et species illustrantes 2: 448pp.

Noyes, J.S. (2001). Interactive catalogue of world. Chalcidoidea 2001. (CD). Dickys Yu, Bentall Centre, Canada.

Perkins (1910). Fauna Hawaiiensis -- supplement to Hymenoptera 2, Part 6: 600-686, London.

Pruthi, H.S. and M.S. Mani (1940). Biologcial notes on Indian arasitic Chalcidoidea. Indian Council of Agricultural Research, New Delhi Miscellaneous Bulletin (30): 1-43.

Ratzeburg, J.T.C. (1844). Die Ichneumonen der Forstinsecten in entomologischen und forstlicher Beziehung 1: 22 pp+4 pls., Berlin. Ratzeburg, J.T.C. (1852). Die Ichneumonen der Forstinsecten 3. viviii $272 \mathrm{pp}+3$ tables, Berlin.

Riley, C.V. (1890). An Australian hymenopterous parsite of the fluted sclae. Insect Life 2: 248-250.

Rondani, C. (1875). Note sul moscherino dell uva Bollettino del Comizio Agrario Parmense 8: 145-148. 1 pl.

Rondani,C. (1877). Vesparia parassita non vel minus cognita. Bolletino della societa Entomologica Italiana 9: 166-213. pls. 3-6.

Saraswat, G.G. and M.K. Mukerjee (1975). Records of some known and descriptions of some new species of Chalcids (Hymenoptera) from India. Contributions No.221. School of Entomology, St. John's College, Agra (4): 35-62.

Spionola, M. (1811). Essai d une nonvelle classification des Diplpleaires Annales du Museum dittistoire Naturelle (Paris) 17. 145152.

Subba Rao, B.R. (1973). Decriptions of a new species and genus of Pteromalidae (Hymenoptera) parasitic on Pachydiplosis oryzae (WoodMason) (Diptera: Cecidomyiidae). Bulletin of Entomological Research 62: 627-629.

Subba Rao, B.R. (1981). Descriptions of new species of Pteromalidae from the Orient (Hymenoptera: Chalcidoidea). Proceedings of the Indian Academy of Science (Biology) 90: 473-4872.

Sureshan, P.M. (1999a). First record of Storeyinae, a very rare subfamily of Pteromalidae (Hymenoptera: Chalcidoidea) from India with the description of a new species. Zoos' Print 14(3-12): 157-158. Sureshan, P.M. (1999b). A new species of Heydenia Forster (Hymenoptera: Pteromalidae) from India. Zoos'Print Journal 15(2): 197-198.

Sureshan, P.M. (1999c). Two new genera and three new species of Pteromalidae (Hymenoptera: Chalcidoidea) from India. Oriental Insects 33: 99-107.

Sureshan, P.M. (2000a). Studies on Chlorocytus Graham (Hymenoptera: Chalcidoidea: Pteromalidae) of the Indian subcontinent 
with the description of a new species. Records of the Zoological Survey of India 98(2): 141-145.

Sureshan, P.M. (2000b). Taxonomic studies on Merismomorpha with description of three new species from India (Hymenoptera: Chalcidoidea: Pteromalidae). Records of the Zoological Survey of India 98(3): 103-110.

Sureshan, P.M. (2001a). A taxonomic revision of the genus Halticopterella (Hymenoptera: Chalcidoidea: Pteromalidae). Oriental Insects 35: 29-38.

Sureshan, P.M. (2001b). Taxonomic studies on Psilocera from India (Hymenoptera: Chalcidoidea; Pteromalidae). Oriental Insects 35: 8390.

Sureshan, P.M. (2001c). Studies on Pteromalus Swederus (Hymenoptera: Chalcidoidea: Pteromalidae) of the Indian Subcontinent with the description of three new species. Records of the Zoological Survey of India 99(1-4): 5-14.

Sureshan, P.M. (2002a). Insecta: Hymenoptera: Chalcidoidea. Fauna of Eravikulam National Park. Zoological Survey of India Conservation Area Series (13): 21-33.

Sureshan, P.M. (2002b). Taxonomic studies on Callitula Spinola with the description of four new species from Indian Subcontinent (Hymenoptera: Chalcidoidea: Pteromalidae). Records of the Zoological Survey of India 100(1-2): 21-30.

Sureshan, P.M. (2003a). Pteromalinae (Pteromalidae: Chalcidoidea: Hymenoptera) of Indian subcontinent. Records of the Zoological Survey of India. Occassional paper (205): 1-170.

Sureshan, P.M. (2003b). On the Indian species of Halticoptera Spinola (Hymenoptera: Chalcidoidea: Pteromalidae). Records of the Zoological Survey of India 100(1-2): 231-237.

Sureshan, P.M. (in press). Taxonomic studies on Cyclogastrella Bukowski and Psilocera Walker (Hymenoptera: Chalcidoidea: Pteromalidae) with the description of a new species from the Oriental Region. Hexapoda.

Sureshan, P.M. and T.C. Narendran (1990). Taxonomic studies on Eurydinotomorpha and Netomocera (Hymenoptera: Chalcidoidea: Pteromlaidae). Oriental Insects 24: 219-227.

Sureshan, P.M. and T.C. Narendran (1994a). A new species of a little known genus of Pteromalidae (Hymenoptera: Chalcidoidea) from India. Records of the Zoological Survey of India 94(1): 113-117.

Sureshan, P.M. and T.C. Narendran (1994b). New species and new record of Pteromalidae (Hymenoptera: Chalcidoidea) from India. Hexapoda 6(2): 59-64.

Sureshan, P.M. and T.C. Narendran (1995a). Two new species of Psilocera (Hymenoptera: Chalcidoidea: Pteromalidae) from India. Journal of Ecobiology 7(3): 209-212.

Sureshan, P.M. and T.C. Narendran (1995b). A new genus of Pteromalidae (Hymenoptera: Chalcidoidea) from Coorg, Karnataka. Journal of the Bombay Natural History Society 92: 96-99.

Sureshan, P.M. and T.C. Narendran (1996). A new species of Agiommatus Crawford (Hymenoptera: Pteromalidae) - an egg parasite of a cutworm on mulberry in Bangalore (Karnataka). Journal of the Bombay Natural History Society 93: 59-61.

Sureshan, P.M. and T.C. Narendran (1997a). Two new species of Pteromalidae (Hymenoptera: Chalcidoidea) from India. Hexapoda 9(1\&2): 27-31.

Sureshan, P.M. and T.C. Narendran (1997b). Studies on Sphegigaster Spinola (Hymenoptera: Chalcidoidea: Pteromalidae) from India. Entomon 22(3\&4): 193-198.

Sureshan, P.M. and T.C. Narendran (1998). A new genus and two new species of Pteromalidae (Hymenoptera:Chalcidoidea) from India. Oriental Insects 32: 185-190.

Sureshan, P.M. and T.C. Narendran (1999a). Two new genera and three new species of Pteromalidae (Hymenoptera:Chalcidoidea) from India. Oriental Insects 33: 99-107.

Sureshan, P.M. and T.C. Narendran (1999b). On the Indian species of Syntomopus Walker (Hymenoptera: Chalcidoidea: Pteromalidae) Records of the Zoological Survey of India 97(4): 83-89.

Sureshan, P.M. and T.C. Narendran (2000a). Three new species of Pteromalidae (Hymenoptera: Chalcidoidea) from India. Journal of the Bombay Natural History Society 97(3): 403-407.

Sureshan, P.M. and T.C. Narendran (2000b). Another Indian species of Homoporus Thomson (Hymenoptera: Chalcidoidea: Pteromalidae). Zoos' Print Journal 16(1): 391-394.

Sureshan, P.M. and T.C. Narendran (2000c). Pteromalidae (Chalcidoidea: Hymenoptera) from India with the description of a new species. Entomon 25(2): 117-128.

Sureshan, P.M. and T.C. Narendran (2001a). Taxonomic studies on Dinarmus Thomson (Hymenoptera: Chalcidoidea: Pteromalidae) of India and adjacent countries. Zoos'Print Journal 16(12): 643-650. Sureshan, P.M. and T.C. Narendran (2001b). A new species of Sphegigaster Spinola from the Indian subcontinent (Hymenoptera: Chalcidoidea: Pteromalidae). Zoos'Print Journal 17(1): 671-674.

Sureshan, P.M. and T.C. Narendran (2001c). On the Indian species of Trichomalopsis Crawford (Hymenoptera: Chalcidoidea: Pteromalidae). Journal of the Bombay Natural History Society 98(3): 396-405.

Sureshan, P.M. and T.C. Narendran (2002a). Three new species of Mesopolobus Westwood (Hymenoptera: Chalcidoidea: Pteromalidae) from India. Entomon 27(1): 79-85.

Sureshan, P.M. and T.C. Narendran (2002b). Studies on Oxysychus Delucchi (Hymenoptera: Chalcidoidea: Pteromalidae) from India with the description of a new species. Journal of the Bombay Natural History Society 99(1): 72-78.

Sureshan, P.M. and T.C. Narendran (2002c). The species of Metastenus Walker and Acroclisoides Girault \& Dodd (Hymenoptera: Chalcidoidea: Pteromalidae) from India. Records of the Zoological Survey of India 100(3-4): 123-131.

Swederus, N.S. (1795). Beskrifning pa et. nytt genus Pteromalus ibland Insecterna hoerande til Hymenoptera k. svenska vetensk Kunglia Svenska Vetenskapsakademiens Handlinger 16, 201-205, 216-222.

Szelenyi, G. (1941). Ueber die Chalcididen-Gattungen Arthrolysis Fortster and Picroscytus Thomas (Hymenoptera). Ann. Mus. natn. Lung.(Zool) 34: 117-131.

Thomson, C.G. (1876). Hymenoptera Scandinaviae. Tom. iv. Pteromalus (Svederus). 259pp., Lundae.

Thomson,C.G. (1878). Hymenoptera Scandinaviae 5. Pteromaluas (Svederus) continuatio 307pp. 1pl. Lund.

Timberlake, P.H. (1926). New species of Hawaiian chalcid flies (Hymenoptera). Proceedings of the Hawaiian Entomological Society. 6: 305-320+pl.x.

Walker, F. (1833). Monographia chalciditum. Entomological Magazine 1: 367-384, 455-466.

Walker, F. (1834). Monographia chalciditum. Entomological Magazine 2: 148-179, 286-309, 340-369.

Walker,F. (1835). Monographia chalciditum. Entomological Magazine 2: 476-501.

Walker, F. (1836). Monographia chalciditum. Entomological Magazine 3: 465-496. 


\section{Checklist of species of the family Pteromalidae of the Indian subcontinent}

\author{
SUBFAMILY: CLEONYMINAE \\ Genus Cleonymus Latreille, 1809 \\ Cleonymus sp. indet. \\ India: Uttar Pradesh. \\ Sri Lanka.
}

*Genus Grooca Sureshan \& Narendran, 1995b

Grooca coorgensis Sureshan \& Narendran, 1995b

India: Karnataka: Coorg District: Nemanakolly; wet

evergreen forest

Probably a parasite of beetles.

Genus Heydenia Forster, 1856

Heydenia tuberculata Sureshan, 1999b

India: Karnataka: Coorg District: Chitekanum; evergreen forest.

Heydenia indica Narendran et al., 2001a

India: Jammu \& Kashmir: Srinagar

Parasite of Scolytus sp. on apple.

Genus Notanisus Walker, 1837

Notanisus sp. indet.

India: Tamil Nadu: Eastern Ghats

Genus Oodera Westwood, 1874

Oodera ahoma (Mani \& Kaul in Mani et al., 1973) India: Assam: Lumding.

Sri Lanka: Galle District: Udugama: Kenneliya Jungle. Pakistan.

Oodera longicollis (Cameron, 1903)

Burma: Pyinmana: Yanaungmyin Reserve and Myitkyina, Bilumyo Rerserve, ex. wood of Tectona grandis.

Genus Parepistenia Dodd in Girault, 1915d

Parepistenia sp. indet.

Sri Lanka.

Genus Riekisura Boucek, 1988

Riekisura keralensis Narendran, 1992

India: Kerala: Pathanamthitta District: Konni Teak forest

Genus Soleneura Westwood, 1868

Soeneura ania (Walker, 1846)

India: Uttaranchal: Dehra Dun; Assam.

Sri Lanka: Amp District: Ekgal Aru Reservoir jungle; Anu District: Padaviya Tank, Tri. District; Trincomalee; China Bay Ridge Bungalow. (Indonesia, Philippines).

Soleneura feretrius (Walker, 1846)

Sri Lanka (Malaysia).

SUBFAMILY: STOREYINAE

Genus Storeya Boucek, 1988

Storeya minuta Sureshan, 1999a

India: Kerala: Idukki District: Eravikulam NP: Sambamalai: Montane grassland.

\section{SUBFAMILY: ORMOCERINAE}

Genus Systasis Walker, 1834

Systasis cenchrivora Farooqi \& Menon, 1972

India: Delhi

Phytophagous in seeds of Cenchrus ciliaris

Systasis dalbergiae Mani, 1942

India: Uttaranchal: Dehra Dun

Parasite of Contarinia dalbergiae making galls on Dalbergia sissoo.

Systasis dasyneurae Mani, 1939

India: Bihar, Haryana, Maharashtra: Nagpur, Uttar Pradesh: Allahabad, Madhya Pradesh: Jabalpur Parasite of Dasyneura lini

Systasis nigra Sureshan, 2002a

India: Kerala: Idukki District: Eravikulam NP: Rajamalai, montane grassland.

Systasis vishnu (Motschulsky, 1863)

Sri Lanka: Mt. Nuwara Eliya.

*Genus Ecrizotomorpha Mani, 1939

Ecrizotomorpha tashkiri Mani, 1939

India: Haryana: Karnal

Hyperparasitic on Dasyneura lini; Bihar (Pruthi \& Mani, 1940: 9).

\section{SUBFAMILY: COELOCYBINAE}

Genus Erotolepsiella Girault, 1915e

Erotolepsiella indica Narendan, 2001

India: Kerala: Malappuram District: Calicut University campus: scrub jungle.

\section{SUBFAMILY: DIPARINAE}

Genus Dipara Walker, 1833

Dipara keralensis Narendran \& Sureshan, 2001

India: Kerala: Parambikulam WLS: Parambikulam, dry deciduous forest.

Dipara miniae Narendran \& Sureshan, 2001 India: Kerala: Palghat District: Chindaki RF

Dipara mohanae Narendran \& Sureshan, 2001 India: Kerala: Calicut District: Thiruvannoor: homestead vegetation.

Genus Grahamisia Delucchi, 1962

Grahamisia malabarensis Narendran, 2000

India: Kerala: Malappuram District: Calicut University campus, scrub jungle.

Genus Netomocera Boucek, 1954 Netomocera nigra Sureshan \& Narendran, 1990 India: Kerala: Malappuram District: Calicut University campus, scrub jungle; Thrissur District: Peechi, dry deciduous forest.

Genus Parurios Girault, 1913b

Parurios keralensis Narendran, 2000
India: Kerala: Idukki District: Moolamattom, scrub jungle; Malappuram District, Nilambur, dry deciduous forest; Kozhikode District: Anakampoyil, scrub jungle.

\section{SUBFAMILY: CEROCEPHALINAE}

Genus Cerocephala Westwood, 1832

Cerocephala dinoderi Gahan, 1925

India: Karnataka: Mysore: ex. Sitophilus oryzae.

Sri Lanka: Thwaites: Peradeniya: ex. Sitophilus oryzae. (Philippines).

Genus Choetospilisca Hedqvist, 1969

Choetospilisca indica Mukerjee in Saraswat \& Mukerjee, 1975

India: Tamil Nadu: Yercaud: Eastern Ghats.

Genus Theocolax Westwood, 1832.

Theocolax elegans (Westwood, 1874)

India: Kerala; Tamil Nadu; Karnataka; Delhi ex. Sitophilus oryzae, stored grain pests (Cosmopolitan).

SUBFAMILY: SPALANGINAE

Genus Spalangia Latreille, 1805

Spalangia cameroni Perkins, 1910

India: Delhi, Karnataka: Bangalore

Parasites of dipterous puparia mainly of synanthropic species (Cosmopolitan).

Spalangia endius Walker, 1839.

India: Chandigarh, Delhi.

Parasites of fly puparia (Cosmopolitan).

Spalangia fuscipes Nees, 1834

India: Andhra Pradesh, Mehboobnagar (Ahmad,1998).

Spalangia gemina Boucek, 1963

India: Bengal; Karnataka; Tamil Nadu

Parasites of Dipterous puparia (Malaysia)

Spalangia nigroaenea Curtis, 1839

India: Delhi, ex. Chrysomyia aenea; Maharashtra; Karnataka: Bangalore; Poultry manure, parasites of fly puparia especially of synanthropic species.

Bangladesh: Dhaka, ex. Musca domestica; Pakistan: Rawalpindi (Cosmopolitan).

Spalangia obscura Boucek, 1963 India: Karnataka: Kamalashile, ex. Tachnid in Tirathaba mundella (Malaysia, Philippines)

Spalangia parfuscipes Ahmad, 1998 India: Uttar Pradesh: Muzaffarnagar.

Spalangia simplex Perkins, 1910 India: Uttar Pradesh (Ahmad,1998).

SUBFAMILY: ASAPHINAE

Genus Asaphes Walker, 1834

Asaphes suspensus (Nees,1834)

India: Kashmir: Srinagar, ex aphidiines in Macrosiphum sp. in Rosa, Macrosiphoniella 
artemisiella on Artemisia, Brevicoryne brassicae on Brassica campestris, exAphidius, Ephedrus, Toxares and Trioxys sp. in various aphids; Punjab: Jalandhar, ex Diaretiella rapae in Lipaphis erysimi;

Pakistan: Swat, ex aphids on Prunus persica (Europe).

Common hyperparasite of aphids of worldwide distribution.

\section{Asaphes vulgaris Walker, 1834}

India: Meghalaya: Shillong, aphids on Datura; Chaubattia, ex Brachycaudus helichrysi;

Nepal: Kathmandu. (Australia, Europe).

Common, widely distributed hyperparasite of aphids.

\section{SUBFAMILY: HERBERTIINAE}

Genus Herbertia Howard, 1894

Herbertia indica Burks, 1959

India: Madhya Pradesh: Gwalior, parasite of leaf mining dipterous larvae; Madhya Pradesh: Damoh; Karnataka: Balehonnur, ex Tropicomyia coffeae on coffee;

Sri Lanka: Lubugama, ex Melanagromyza sp. (Malaysia).

\section{SUBFAMILY: EUNOTINAE}

* Genus Ajanta Narendran in Narendran \& Mini, 1999

Ajanta malabarensis Narendran in Narendran \& Mini, 1999

India: Kerala: Palakkad District: Malampuzha, grassland; Malappuram District, Calicut University campus, scrub jungle.

\section{Genus Cephaleta Motschulsky, 1859}

Cephaleta australiensis (Howard, 1896)

India: Uttar Pradesh: Aligarh, ex Cerococcus sp.; Assam: Motipur, on Alternantia philoxeroides; Orissa: Bhubaneswar, ex coccids on Hibiscus; Maharashtra: Nasik ex Cerococcus sp., Andhra Pradesh: Hyderabad, ex mealybug on Cajanus cajan.

Sri Lanka: Ambepussa, ex coccids on Tephrosia candida; Bangladesh: Dhaka, ex Ferrisia virgata, ex coccids on cotton.

Pakistan: Sialkot, ex coccid on Hibiscus rosasinensis. (Australia)

Cephaleta brunniventris Motschulsky, 1859

India: Assam: Toklai, ex Asterolecanium sp; Bihar: Sabour, ex Cerococcus hibisci; Uttar Pradesh: Aligarh, ex Ceroplastes pseudoceriferus; Delhi on Ficus; Pondicherry, ex. Chloropulvinaria psidii; Goa: Madgaon; Karnataka: Bangalore, ex coccid on Basella rubra; Balehonnur; Kerala: Thiruvananthapuram, ex Ceroplastes sp.; Calicut, on Coccids; Andaman islands, ex Saissetia coffeae.

Pakistan: Karachi, Azim; Sri Lanka.

Cephaleta nirupama Narendran \& Mini, 1999 India: Tamil Nadu: Mangarai, ex coccids on Acacia nilotica.
Genus Moranila Cameron, 1881

Moranila californica (Howard, 1881)

India: Karnataka: Bangalore, ex Saissetia sp. (Australia, America)

\section{Genus Ophelosia Riley, 1890}

Ophelosia hayati Farooqi, 1984 India.

Ophelosia indica Faroogi, 1983

India: Maharashtra: Nasik, ex Nipaecoccus sp.

Genus Scutellista Motschulsky, 1859

Scutellista caerulea (Fonscolombe, 1832) India: Hosts: coccids Lecanium sp., Saissetia oleae, Parasaissetia nigra.

Sri Lanka: Mt. Patanna. (Cosmopolitan).

Scutellista hayati (Farooqi, 1980)

India. Madhya Pradesh: Hoshangabad; Maharashtra: Manmad; Tamil Nadu: Valandur, on Cerococcus sp.

\section{SUBFAMILY: AUSTROTEROBINAE}

Genus Austroterobia Girault, 1938

Austroterobia maldica Narendran, 2000

India: West Bengal: Malda.

Parasite of Icerya sp. on Mango tree.

\section{SUBFAMILY: PTEROMALINAE}

Genus Acroclisoides Girault \& Dodd, 1915a

Acroclisoides indicus Ferriere, 1931b

India: Uttar Pradesh; Tamil Nadu: Chennai, ex pentatomid eggs.

Burma: N. Toungoo, Gwethe Reserve.

Acroclisoides maculatus Sureshan \& Narendran 2002C

India: Kerala: Calicut University campus, scrub jungle

ex. Pentatomid eggs; Tamil Nadu: Coimbatore, scrub jungle.

Genus Agiommatus Crawford, 1911

Agiommatus geethae Sureshan \& Narendran, 1996 India: Karnataka: Bangalore, ex eggs of Spodoptera litura on mulberry.

Agiommatus paria (Motschulsky, 1863). India: Uttaranchal: Dehra Dun, ex eggs of Acherontia styx;

Sri Lanka: Mts. Nuwura-Eliya and Patannas.

Genus Anisopteromalus Ruschka, 1912

Anisopteromalus calandrae (Howard, 1881)

India: Kerala, Tamil Nadu, ex. Sitophilus oryzae;

Sitiophilus granarium, Tribolium castaneum; Pakistan: Mirpur Khas, ex weevil Athesapeuta cyperi on Cyperus rotundus.

Burma: Mandalay District, Maymyo.

Cosmopoliton parasite of grain weevils and other beetles in stored products.
Genus Callitula Spinola, 1811

Callitula anguloclypea Sureshan, 2002b

India: Kerala, Parambikulam WLS, Orukomban, semi evergreen forest; Thrissur District, Vazhani, Peechi; Kannur District, Aralam; Palakkad District, Malampuzha, dry deciduous forest; Thiruvananthapuram District, Kovalam; Malappuram District, Chungathara, grasslands.

Callitula bambusae Narendran \& Jobiraj in Narendran et al., 2001c

India: Kerala: Thiruvananthapuram, Palode, from Bambusae inflorescence

Callitula keralensis Sureshan, 2002b

India: Kerala: Malappuram District, Vaniyampuzha; Thrissur District: Peechi, dry deciduous forest; Malappuram District: Calicut University Campus; Kannur District: Tellicherry; Kasaragod District: Manjeswaram; Ernakulam, scrub jungle; Palakkad District: Silent Valley, semi evergreen forest.

Callitula peethapada Narendran \& Mohana in Narendran et al., 2001c

India: Kerala: Alappuzha District: Kayamkulam, scrub jungle.

Callitula robusta Sureshan, 2002b

India: Kerala: Parambikulam WLS, Anappady, dry deciduous forest.

Callitula rugosa (Waterston, 1915)

India: Kerala: Malappuram District: Chungathara, Calicut University campus; Kannur District: Payyannur; Alappuzha District: Kayamkulam; Quilon District: Chavara; Thiruvananthapuram District: Thiruvananthapuram, scrub jungle.

Sri Lanka: Peradeniya.

Callitula travancorensis Sureshan, 2002b

India: Kerala: Ernakulam; Quilon District: Chavara; Thiruvananthapuram District: Kattakada, scrub jungle; Palakkad District: Agali, grassland.

Genus Catolaccus Thomson, 1878

Catolaccus crassiceps (Masi, 1911)

India: Punjab: Ludhiana, ex Apanteles glomeratus; Uttaranchal: Dehra Dun, ex Apanteles in Hymenia fascialis; Uttar Pradesh: Aligarh, twig with Centrococcus insolitus; Delhi on Tamarix and on Lucerne.

Pakistan: Bhalwar, ex Platyedra gossypiella; Ringli, ex Characoma nilotica; Wasirabad, ex cocoons of Coniatus indicus on Tamarix dioica. (Europe).

Genus Cheiropachus Westwood, 1828

Cheiropachus quadrum (Fabricius, 1787)

India: Himachal Pradesh: Mashobra, on cherry bark; Jammu \& Kashmir, ex Scolytus sp. on apple tree. Pakistan: Quetta, in twigs of Malus pumila? (Europe, America). 
Genus Chlorocytus Graham, 1956a

Chlorocytus indicus Sureshan, 2000a

India: Throughout Kerala, Grass lands

Chlorocytus murriensis Graham, 1965

Pakistan: Murree

Chlorocytus xanthopus (Cameron, 1906)

India: Delhi.

Pakistan: Quetta.

Genus Conomorium Masi, 1924a

Conomorium sp. indet.

India: Uttar Pradesh.

Genus Coruna Walker, 1833

Coruna clavata Walker, 1833

India: Kashmir: Srinagar ex Trioxys indicus in Macrosiphum sp. (Europe).

Genus Cryptoprymna Forster, 1833

Cryptoprymna brama (Motschulsky, 1863)

Sri Lanka: Thwaites. (Malaysia).

Cryptopryma elongata Sureshan \& Narendran, 2000a

India: Kerala: Idukki District,Kulamavu; Palakkad

District: Mukali; Wynad District: Mananthavady, scrub jungle.

Cryptoprymna indiana Sureshan \& Narendran, 2000a

India: Kerala: Thrissur District, Peechi; Palakkad District: Silent Valley, Anakkaty; Malampuzha, dry deciduous forest

Genus Cyclogastrella Bukowski, 1938

Cyclogastrella nigra Sureshan, in press

India: Kerala: Pathanamthitta District, Muzhiyar, semi evergreen forest.

Genus Cyrtogaster Walker, 1833

Cyrtogaster clavicornis Walker, 1833

India: Kerala: Eravikulam NP: Eravikulam, Bhimnada, montane grassland (Sureshan, 2002). (Europe, America).

\section{Genus Cyrtoptyx Delucchi, 1956}

Cyrtoptyx latipes (Rondani, 1877)

India: Tamil Nadu: Thirunelveli District, Dohnavur, Coimbatore, ex Hypolixus in Amaranthus.

Pakistan: Islamabad, ex Cydia sinana in stem of Cannabis sativa; Rawalpindi, ex Hypolixus truncatulus in Amaranthus spinosus; Khushab, ex larva in Cypparis decidua. (Europe).

Genus Delislea Girault, 1936

Delislea rahimani Narendran \& Anil in Narendran et al., 1992b

India: Kerala: Alappuzha District: Kayamkulam

Hyperparasitic on the cocoon of Apanteles taragamae on Opisina arenosella.
Genus Dibrachys Forster, 1856

Dibrachys cavus (Walker, 1835)

India: Himachal Pradesh, ex soil with pupae of Ectropis deodarae. (Cosmopolitan).

Genus Dinarmus Thomson, 1878

Dinarmus acutus (Thomson, 1878)

India: Kerala (Europe, Africa).

Dinarmus altifrons (Walker, 1862)

India: Uttaranchal, Dehra Dun, ex Caryedon gonagra, indet. bruchids; Punjab: Ludhiana, ex bruchid on Sesbania acutifolia; Delhi, on Sesbania; Tamil Nadu: North Salem, Jawalagiri; Coimbatore, from seeds of Albizia lebbeck (Sureshan, 2001).

Pakistan: Karrat, ex pods of Pueraria tuberosa; Karachi, ex bruchid. (Europe, Africa).

Dinarmus basalis (Rondani, 1877)

India: Rajasthan: Udaipur, ex bruchids; Delhi, ex bruchid; Jharkhand: Dholi, on wild chillies; Haryana, ex Trogoderma granarium; Andhra Pradesh: Hyderabad, stored grain; Karnataka: Bangalore. Pakistan: Karachi; Bangladesh. (Europe, Africa, Thailand).

Dinarmus colemani (Crawford, 1913)

India: Kerala: Thrissur District, Changaramkulam, scrub jungle (Sureshan \& Narendran, 2001a); Karnataka: Bangalore; Tamil Nadu; Delhi, exCallosobrucus chinensis, on grass; Jharkhand: Dholi, on wild chillies.

Bangladesh: Dhaka.

Dinarmus maculatus (Masi, 1924)

India: Throughout Kerala, all types of vegetations; Burma.

Dinarmus vagabundus (Timberlake, 1926)

India: Punjab, Karnataka, Tamil Nadu and Kerala: from stored pulses infested with beetles.

Pakistan: Karachi.

Sri Lanka: Peradeniya. (Vietnam, Africa).

Genus Eunerua Walker, 1844

Euneura lachni (Ashmead, 1877)

Pakistan: Quetta, on Myzus persicae (= Lachnus sp.

(Europe, America).

Hyperparasitic in aphids.

Genus Eurydinotomorpha Girault, 1913

Eurydinotomorpha malabarensis Sureshan \& Narendran, 1990

India: Kerala: Malappuram District, Calicut University campus, scrub jungle.

Eurydinotomorpha petiolatus (Boucek, 1973). Sri Lanka. (Malaysia)

Genus Halticopterella Girault \& Dodd, 1915

Halticopterella burwelli Sureshan, 2001a

India: Kerala: Kannur District, Kottiyoor, semi evergreen forest; Wynad District: Appappara RF;
Palakkad District: Parambikulam WLS; Pathanamthitta District: Konni, dry deciduous forest.

Halticopterella longiflagellum Sureshan, 2001a India: Kerala: Wynad District, Thirunelli; Pathanamthitta District: Muzhiyar, evergreen forest.

Halticopterella rampurensis Sureshan, 2001a India: Kerala: Wynad District: Rampur, evergreen forest; Ottappara, evergreen forest.

Halticopterella robusta Sureshan, 2001a

India: Kerala, Thrissur District, Peechi, deciduous forest; Alappuzha District: Kayamkulam, scrub jungle.

Genus Homoporus Thomson, 1878

Homoporus acuminatus Sureshan \& Narendran, 2000b

India: Kerala: Kozhikode District: Calicut, scrub jungle; Palakkad District: Parambikulam WLS, dry deciduous forest.

Homoporus gladiatus Sureshan \& Narendran, 2000c

India: Kerala: Kozhikode District, Thiruvannor; homestead vegetation; Kasaragod District: Neeleswaram; Palakkad District: Malampuzha, Mukali; Malappuram District, Calicut University Campus. Mukali, scrub jungle.

Genus Inkaka Girault, 1939

Inkaka keralensis Sureshan \& Narendran, 1997a India: Kerala, Kasaragod District, Manjeswaram; Malappuram District: Thalappara; Palakkad District: Malampuzha, grass land.

Genus Ischyroptyx Delucchi, 1956

Ischyroptyx sp. indet.

India: Delhi, Bihar.

* Genus Kumarella Sureshan, 1999

Kumarella angulus Sureshan, 1999c

India: Kerala: Palakkad District: Parambikulam WLS, Tellickal, Sirkarpathi-I, dry deciduous forest; Malappuram District: Calicut University campus, scrub jungle.

Kumarella sandroi Narendran \& Mohana in Narendran et al., 2001.

India: Kerala: Wynad District: Sultan's Battery, semi evergreen forest.

Genus Lariophagus Crawford, 1909

Lariophagus distinguendus (Forster,1841).

India: Throughout Kerala; Tamil Nadu; Nepal: Kathmandu. (Cosmopolitan).

Parasite of grain weevil and other beetles attacking stored grains, in particular Sitophilus spp.

* Genus Manineura Boucek, 1978

Manineura pentatomivora (Mani, 1939)

India: Eastern Himalaya: Kalimpong; North Bengal, 
parasitic in the eggs of Pentatomid Urostylis punctigera

Genus Merismomorpha Girault, 1913a

Merismomorpha elongata Sureshan, 2000b

India: Kerala: Palakkad District: Agali, grassland

Merismomorpha minuta Sureshan, 2000b India: Kerala: Palakkad District: Malampuzha; Wynad District: Tirunelli; Malappuram District: Calicut University campus, scrub jungle.

Merismomorpha truncata Sureshan, 2000b India: Kerala: Malappuram District: Calicut University Campus, scrub jungle.

Merismomorpha yousufi Ahmad \& Agarwal, 1994 India: Uttar Pradesh: Nainital.

Genus Mesopolobus Westwood, 1833

Mesopolobus harithus Sureshan \& Narendran, 2002a

India: Kerala: Palakkad District: Silent Valley, evergreen forest.

Mesopolobus keralensis Sureshan \& Narendran, 2002a

India: Throughout Kerala, scrub jungle.

Mesopolobus minutus Sureshan \& Narendran, 2002a

India: Kerala, Thrissur District: Vazhani, dry deciduous forest; Idukki District: Eravikulam NP, Turner's hill, montane grassland; Ernakulam, Pathanamthitta District: Konni; Kannur District: Tellicherry, scrub jungle.

Genus Metacolus Forster, 1856

Metacolus beesoni (Mani \& Kaul,1973)

India: Simla, Kashmir, Uttar Pradesh. (Israel).

Metacolus unifasciatus (Forster, 1856)

India: Himachal Pradesh: Dokhri, (Europe).

Genus Metastenus Walker, 1834

Metastenus concinnus Walker, 1834

India: Kerala: Kottayam, with coccids; (Europe).

Metastenus indicus Sureshan \& Narendran, 2002c India: throughout Kerala. All type of vegetations.

Genus Miscogasteriella Girault, 1915c

Miscogasteriella jayasreeae Sureshan, 1999c India: Kerala: Parambikulam WLS: Thellickal, dry deciduous forest.

Genus Mokrzeckia Mokrzecki, 1933

Mokrzekia menzeli Subba Rao, 1973

India: Uttaranchal: Dehra Dun, hyperparasitic on Hapalia machaeralis through Apanteles malevolus; Hybloea purea, through Miocolus dubius; exApanteles oblique; indet. cocoons. Kerala: Eravikulam NP: Sambamalai, Rajamalai, montane grassland.
Mokrzeckia orientalis Subba Rao, 1973 India: Karnataka, Maharashtra, and Uttar Pradesh, parasite in cocoons of Apanteles sp.

Sri Lanka: Talawakelle, with Hamonia coffearea, (Indonesia, Thailand)

* Genus Narendrella Sureshan, 1999c

Narendrella nilamburensis Sureshan, 1999c

India: Kerala: Malappuram District: Nilambur; Kannur District: Nedumpoyil; Palakkad District: Parambikulam WLS: Anappady, dry deciduous forests; Malappuram District: Calicut University campus; Alappuzha District: Kayamkulam, scrub jungle.

Genus Nasonia Ashmead, 1904

Nasonia vitripennis (Walker, 1836)

India: Delhi. (Cosmopolitan).

Genus Norbanus Walker, 1843

Norbanus acuminatus Dutt \& Ferriere, 1961

India: West Bengal, Barrackpore, parasite of Cerambycid beetle Nupserha bicolor; throughout Kerala.

Norbanus birmanus (Masi, 1927) Burma.

Norbanus equs Sureshan, 2003a

India: Throughout Kerala, all type of vegetations.

Norbanus indorum (Masi, 1927)

India: Orissa; Pakistan: Sheikapura, ex borer in Cyperaceae.

Norbanus malabarensis Sureshan, 2003a

India: Kerala: Palghat District, Silent Valley; Thrissur District: Vazhani, moist deciduous forest.

Norbanus scrobatus Sureshan, 2003a

India: Kerala: Palghat District, Silent Valley; Quilon District: Kuravanthavalam, semi evergreen forest.

Norbanus thekkadiensis Sureshan, 2003a

India: Kerala: Idukki District: Thekkadi; Palakkad District, Malampuzha; Malappuram District: Chungathara, moist deciduous forest; Karnataka: Coorg District, Ottekolly, semi evergreen forest.

Genus Notoglyptus Masi, 1917.

Notoglyptus scutellaris (Dodd \& Girault ,1915a)

India: Uttar Pradesh: Aligarh; Delhi; Kerala. (Europe, Japan, South Africa, America, Australia).

Genus Oniticellobia Boucek, 1976

Oniticellobia longigastra Sureshan \& Narendran, 1994a

India: Alappuzha District, Kayamkulam; Ernakulam; Pathanamthitta District: Konni; Malappuram District,

Calicut University campus, scrub jungle; Palakkad District: Parambikulam WLS, Venkloi, Parambikulam, dry deciduous forest.
* Genus Oricoruna Boucek, 1978

Oricoruna arcotensis (Mani \& Kurian, 1953) India: Jharkhand: Ranchi, in cage with Indian lac infested by Icerya aegyptiaca; Karnataka: Bangalore.

Genus Oxysychus Delucchi, 1956

Oxysychus coimbatorensis (Ferriere, 1939)

India: Tamil Nadu: Coimbatore; Andhra Pradesh; Bihar: Pusa; Delhi; Kerala.

Pakistan: Sialkot, ex stem of Amaranthus viridis ex. Hypolixus truncatulus, Pempherulus affinis.

Oxysychus macregaster Sureshan \& Narendran, 2002b

India: Kerala: Malappuram District: Calicut University Campus; Thrissur District: Peechi; Alappuzha District: Shertallai, scrub jungle.

Oxysychus nupserhae (Dutt \& Ferriere, 1961)

India: West Bengal; Kerala: Parambikulam WLS; Wynad District: Nanchal, dry deciduous forest; Thiruvananthapuram District: Kazhakuttom; Malappuram District: Calicut University campus, scrub jungle.

Parasite of Nupserha bicolor girdling jute stem

Oxysychus sphenopterae (Ferriere, 1931a) India: Punjab, parasite of larvae of Sphenoptera gossypii (Africa)

Genus Pachycrepoideus Ashmead, 1904

Pachycrepoideus veerannai Narendran \& Anil in Narendran et al., 1992a

India: Karnataka: Bangalore, pupa parasite of Exorista sorbillans on Bombyx mori .

Pachycrepoideus vindemmiae (Rondani, 1875) India: Chandigarh, ex Musca domestica; Maharashtra: Nagpur, ex dipterous pupae, ex Orseolia oryzae; Karnataka: Bangalore, ex pupae in poultry manure; Tamil Nadu: Madurai, ex tachinid pupa. (Europe).

Genus Pachyneuron Walker, 1833

Pachyneuron aeneum Masi, 1929

India: Delhi; Uttar Pradesh: Aligarh; Maharashtra: Pune, ex syrphid puparium. (Europe).

Pachyneuron ahlaense Mani \& Saraswat, 1974 India: Delhi; Himachal Pradesh; Karnataka: Bangalore, ex syrphid puparium.

Pachyneuron aphidis (Bouche, 1834)

India: Kashmir: Srinagar, ex Myzus sp. on Prunus domestica, ex Aphidius sp. in Macrosiphum sp.; Delhi; Haryana.

Pakistan: Swat, ex aphids on Prunus persica. (Europe).

Pachyneuron chambaense Mani \& Saraswat, 1974 India: Himachal Pradesh.

Pachyneuron groenlandicum (Holmgren, 1872) India: Kashmir: Srinagar with Brachydacudus sp. on 
Cardus; Delhi; Orissa: Bhubaneswar, ex syrphid; Kerala: Palakkad District: Kalkandi; Tamil Nadu; Karnataka: Bangalore, ex. Ishiodon sp. on Cassia sp. Himachal Pradesh: Haryana. (Europe).

Pachyneuron leucopiscida Mani, 1939 India: Tamil Nadu: Coimbatore, ex Leucopis nigricornis on Zea mays; Bihar: Pusa, with Dactylopius sp. on cotton.

Pachyneuron solitarium (Hartig, 1838) India: Kerala: Quilon District: Kottayam (Sureshan \& Narendran, 2000 c) (Europe, Japan).

Genus Paracarotomus Ashmead, 1894

Paracarotomus cephalotes Ashmead, 1894

India: Karnataka: Bangalore, ex syrphid. (Australia America, Europe)

* Genus Paraiemea Sureshan \& Narendran, 1998 Paraiemea convexa Sureshan \& Narendran, 1998 India: Kerala: Malappuram District; Calicut University campus, scrub jungle.

Paraiemea vishnuae Sureshan \& Narendran, 1998 India: Kerala: Idukki WLS, Vellaikamali; Palakkad District: Silent Valley; Wynad District: Puzhamudi; Thrissur District: Peechi, semi evergreen forest.

Genus Platecrizotes Ferriere, 1934

Platecrizotes sp. indet.

India: Tamil Nadu.

Genus Propicroscytus Szelenyi, 1941

Propicroscytus mirificus (Girault, 1915c)

India: Throughout Kerala, grass lands; Uttar Pradesh: Aligarh, parasite of gall midges in rice and stems of other grasses.

Sri Lanka. (Australia).

Propicroscytus oryzae (Subba Rao, 1973)

India: Throughout Kerala; Orissa; Maharashtra; Andhra Pradesh, parasite of Orseolia oryzae, ex paddy gall fly.

Sri Lanka.

Genus Psilocera Walker, 1833

Psilocera clavata Sureshan \& Narendran, 1995a India: Kerala: Malappuram District: Calicut University campus, scrub jungle.

Psilocera clavicornis (Ashmead, 1904)

Sri Lanka. (South America).

Psilocera ghanii Subba Rao, 1981

Pakistan: Babakewal. parasitic on Cryptocephalus faustulus on Tamarix diocia.

Psilocera heydoni Sureshan, 2001b India: Karnataka: Coorg District: Nemanakolly RF, Otekolly RF.

Psilocera scutellata Sureshan, 2001b

India: Kerala: Malappuram District: Calicut University
Campus, scrub jungle; Palakkad District: Parambikulam WLS, dry deciduous forest.

Psilocera vinayaki Sureshan \& Narendran, 1995a India: Kerala: Kasaragod; Malappuram District Calicut University campus; Alappuuzha District: Kayamkulam; Kannur District: Payyannur, scrub jungle; Waynad District: Puzhamudi; Idukki District: Thekkadi, dry deciduous forest.

Genus Pteromalus Swederus, 1795

Pteromalus keralensis Sureshan, 2001 India: Throughout Kerala, all types vegetations

Pteromalus metallicus Sureshan, 2001c India: Throughout Kerala, grass lands and cultivated fields.

Pteromalus nigrus Sureshan, 2001c India: Kerala: Palakkad District: Malampuzha; Kalkandi, dry deciduous forest.

Pteromalus puparum (Linnaeus, 1758)

India: Kerala: Palakkad District: Anakkatty; Mukali; Wynad District: Sultan's Battery, grassland Uttaranchal: Dehra Dun; Bihar: Pusa; Meghalaya: Shillong. (Cosmopolitan).

Pteromalus semotus (Walker, 1834)

India: Throughout Kerala; common parasite in pupae of various lepidoptera and certain beetles.

Pakistan. (Europe).

Pteromalus sequester Walker, 1835

India: Punjab on Sesbania acutifolia; Delhi on Lucerne. (Europe).

\section{Genus Rhaphitelus Walker, 1834}

Rhaphitelus maculatus Walker, 1834

India: Kashmir, parasite of Scolytus sp. on apple (Narendran, et al., 2001a) (Europe, Australia, America).

Genus Rhopalicus Forster, 1856

Rhopalicus sp. indet.

India: Meghalaya: Shillong, Khasi Hills, ex Blastophagus khasianus on Pinus khasia.

Genus Roptrocerus Ratzeburg, 1844

Roptrocerus xylophagorum (Ratzeburg, 1844) India: Uttaranchal: Dehra Dun, parasite of bark beetles (Scolytidae). (Europe, N. America).

Genus Schizonotus Ratzeburg, 1852

Schizonotus latus (Walker, 1833)

Pakistan: Lyalpur, ex Chrysomelid on Populus. (Europe).

Schizonotus sieboldi (Ratzeburg, 1852)

Pakistan: Murree, ex coccinellid pupa on fir. (Europe).

Genus Sphegigaster Spinola, 1811

Sphegigaster anamudiensis Sureshan \& Narendran 1997b

India: Kerala: Eravikulam NP, Anamudi, montane grassland.

Sphegigaster brunneicornis (Ferriere, 1930)

India: Throughout Kerala, all types of vegetations.

Sri Lanka: Peradeniya ex Ophiomyia phaseoli on beans.

Sphegigaster indica Sureshan \& Narendran, 2001b India: Kerala: Parambikulam WLS: Orukomban, evergreen forest.

Sphegigaster reticulata Sureshan \& Narendran, 1997b

India: Kerala: Palakkad District: Parambikulam, dry deciduous forest.

Sphegigaster stepicola Boucek, 1965

India: Throughout Kerala, all types of vegetations; Karnataka: Bangalore: ex Melanagromyza soyae; Delhi; Bihar; Uttar Pradesh, parasitic on Melanagromyza and Phytomyza sp. (Europe, Austria, Algeria).

Genus Sphegigastrella Masi, 1917

Sphegigastrella sp. indet.

Sri Lanka. (Africa).

Genus Syntomopus Walker, 1833

Syntomopus carinatus Sureshan \& Narendran, 1999b

India: Throughout Kerala, forest vegetation.

Syntomopus nigrus Sureshan \& Narendran 1999b India: Kerala: Palakkad District: Anakatty, Kalkandi, grassland.

Syntomopus rajamalaiensis Sureshan \& Narendran 1999b

India: Kerala: Eravikulam NP: Rajamalai, montane grassland.

Genus Toxeumorpha Girault, $1915 \mathrm{c}$ Toxeumorpha megacephala (Waterston, 1915)

Sri Lanka: Bandarawela, ex tea leaf-miner Tropicomyia theae.

Toxeumorpha minuta Sureshan \& Narendran, 2000a

India: Kerala: Malappuram District: Calicut University Campus, scrub jungle.

Genus Trichomalopsis Crawford, 1913.

Trichomalopsis acarinata Sureshan \& Narendran, 2001c

India: Kerala, southern districts, cultivated fields.

Trichomalopsis apanteloctena (Crawford ,1911) India: Throughout Kerala, Tamil Nadu, Karnataka, paddy filed.

Bangladesh. (Japan, Korea, Malaysia, China, Taiwan, Philippines, Formosa). 
Trichomalopsis deplanata Kamijo \& Grissell 1982 India: Kerala: Pathanamthitta District: Ranni; Malappuram District: Tenjipalam; Thiruvananthapuram District: Vayalar, paddy field; West Bengal, Tachnid puparia on paddy. (China, Japan, Korea).

Trichomalopsis neelagastra Sureshan \& Narendran, 2001c

India: Kerala: southern districts, paddy and other cultivated fields.

Trichomalopsis nigra Sureshan \& Narendran, 2001c India: Kerala, southern districts, grassland.

Trichomalopsis ovigastra Sureshan \& Narendran, 2001c

India: Kerala, southern districts, paddy field.

Trichomalopsis thekkadiensis Sureshan \& Narendran, 2001c

India: Throughout Kerala, paddy fields and adjacent vegetations.

Trichomalopsis travancorensis Sureshan \& Narendran, 2001c

India: Throughout Kerala, cultivated fields.

Genus Trichomalus Thomson, 1878.

Trichomalus kannurensis Sureshan \& Narendran 1994b

India: Kerala: Kannur District: Aralam farm; Kottayam District: Athirampuzha; Kozhikode District, Peruvannamuzhi; Wynad District: Puzhamudi, grassland.

Trichomalus keralensis Sureshan 2002a

India: Kerala: Eravikulam NP, Rajamali, montane grassland.

Genus Uniclypea Boucek, 1976

Uniclypea elongata Sureshan \& Narendran, 1997a India: Kerala: Parambikulam WLS, dry deciduous forest.

Uniclypea kumarani Sureshan \& Narendran, 1994b India: Kerala: Malappuram District: Calicut University campus; Nilambur, scrub jungle.

\section{SUBFAMILY: MISCOGASTERINAE}

Genus Halticoptera Spinola, 1811

Halticoptera agaliensis Sureshan, 2003b

India: Kerala: Palakkad District: Agali; Malappuram District: Calicut University Campus, scrub jungle.

Halticoptera propinqua (Waterston, 1915)

India: Delhi, on Lucerne; Andhra Pradesh: Hyderabad, on Phaseolus vulgaris; throughout Kerala, grassland. Pakistan.

Sri Lanka: Paradeniya.

Genus Lamprotatus Westwood, 1833

Lamprotatus sp. indet.

India; Nepal. (Boucek, et al., 1979)
Genus Merismus Walker, 1833

Merismus indicus Ahmad, 1997

India: Uttaranchal: Nainital.

Merismus sp. indet.

India: Tamil Nadu; Nepal. (Boucek, et al., 1979).

Genus Miscogaster Walker, 1833

Miscogaster sp. indet.

India: Delhi (Boucek, et al., 1979)

Genus Seladerma Walker, 1834

Seladerma sp. indet.

(Burma) (Boucek, et al., 1979)

Genus Stictomischus Thomson, 1876

Stictomischus turneri Sureshan 2002 a

India: Kerala: Eravikulam NP, Turner's Hill, montane grassland.

Genus Thinodytes Graham, 1956

Thinodytes cyzicus (Walker, 1839)

India: Delhi, on Lucerne, Europe.

\section{SUBFAMILY: PANSTENONINAE}

Genus Panstenon Walker, 1846

Panstenon sp. indet.

India: Kerala (unpublished data, Sureshan)

SUBFAMILY: PIRENINAE

Genus Trigonoderopsis Girault, 1915d

Trigongoderopsis bouceki Ahmad \& Agarwal, 1994 India: Uttar Pradesh: Aligarh.

Genus Gastrancistrus Westwood, 1833

Gastrancistrus agarwali Ahmad, 1995

India: Haryana, Rohtak.

Gastrancistrus (Gastrancistrus) bengalicus

Narendran et al., 2001b

India: West Bengal, Murshidabad, ex. mango gal midge.

Gastrancistrus (Magistrus) cherryi Boucek 1986 India: West Bengal, Malda, ex mango gall midge.

Gastrancistrus (Gastrancistrus) muneswari Yadav, 1978

India: Bihar, Sabour, ex Oligotrophus mangiferae; West Bengal, Murshidabad, ex Rhabdophaga mangiferae.

\section{SUBFAMILY: MACROMESINAE}

Genus Macromesus Walker, 1848

Macromesus harithus Narendran et al., 2001a

India: Kashmir: Srinagar, ex Scolytus sp. on Malus silvestris.

* Endemic to India; Distribution of the species outside Indian subcontinent given in brackets.
Walker, F. (1837). Monographia Chalciditum. Entomological Magazine 4: 439-461.

Walker, F. (1839). Monographia Chalciditum. 333pp. London.

Walker, F. (1843). Descriptions des Chalcidites trouvees au Bluff de saint-Jean dans la Floride Orientale par M.M.E. Doubleday et R. Foster. Annales de u societe entomologique de France 2(1): 145-162.

Walker, F. (1844). Descriptions of some chalcidites of North America collected by George Barnston. Esq. Annals and Magazine of Natural History 14: 14-17.

Walker, F. (1846). List of the specimens of hymenopterous insects in the collection of the British Museum part I. Chalcidites 8+100 pp., London.

Walker, F. (1848). List of the specimens of hymenopterous insects in the collection of British Museum part II. Chalcidites. Additional species. pp.i-iv and 99-239, London.

Walker, F. (1862). Notes on Chalcidites and characters of undescribed species. Transactions of the Entomological Society of London (3)1: 345-397.

Waterston, J.C. (1915). New species of Chalcidoidea from Ceylon. Bulletin of Entomological Research 5: 325-342.

Westwood, J.O. (1828). On the Chalcididae. Zoological Journal of London. 4.3-31+pl.1.

Westwood, J.O. (1832). Cerocephala Westwood - in Guerin F.E.Magasin de zoologie. classe ix. pl.4. Paris.

Westwood, J.O. (1833). Descriptions of several new genera and species of Chalcididae. Proceedings of the Entomological Society of London 1868 xxxv-xxxvii.

Westwood, J.O. (1868). Descriptions of new genera and species of Chalcidoidea. Transactions of the Entomological Society of London $1868 \mathrm{xxxv-xxxvii.}$

Westwood, J.O. (1874). Thesaurus Entomologicus Oxoniensis or illustrations of new rare and interesting insects, for the most part continued in the collections presented to the University of Oxford by the Rev. F.W. Hope 24+205pp.

Yadav, S. (1978). A new sepcies of the genus Gastrancistrus (Pteromalidae: Hymenoptera) from India. Journal of Entomology 40: 466467. 


\section{List of invalid species and species transferred from one genus to another}

Acanthometopon clavicorne Ashmead, 1904 to Psilocera

Acroclisis melanagromyza Mani, 1971 to Sphegigaster

Agiommatus acherontiae Ferriere, 1931 - see Agiommatus paria

Anysis tripathi Kaul, 1974 - to Cephaleta

Asaphes swaraji Sharma \& Subba Rao, 1958 - see Asaphes suspenses

Asoka petiolatus Boucek, 1973 to Eurydinotomorpha

Austrogerrus sp. to Parepistinia

Bruchobius colemani Crawford, 1913 to Dinarmus

Cardiogaster fusciventris Motschulsky, 1863 to Cephaleta

Cephaleta hayat Farooqi, 1980 to Scutellista

Cephaleta purpureiventris Motschulsky,1859 see Cephaleta brunneiventris

Chalcedectus indicus Mani \& Kaul, 1973 unplaced

Choetospila elegans Westwood, 1874 to Theocolax

Dinarmus coimbatorensis Ferriere, 1939 to Oxysychus

Encyrtus obstructus Walker, 1860 to Cephaleta

Epistenia longicollis Cameron, 1903 to Oodera

Etroxys marginicollis Cameron, 1906 to Pteromalus

Etroxys xanthopus Cameron, 1906 to Chlorocytus

Eulophus brama Motschulsky, 1863 to Cryptoprymna

Eulophus paria Motschulsky, 1863 to Agiommatus

Eulophus vischnu, Motschulsky, 1803 to Systasis

Eupteromalus parnarae Gahan, 1919 to Trichomalopsis

Eurycephalus alcocki Ashmead, 1903 to Cephaleta

Eurycranium saissetiae Ashmead, 1905 to Cephaleta

Gastrancistrus mangiferae Rao, 1981 see Gastrancistrus (G) muneswari

Lycisca ahoma Mani \& Kaul, 1973 to Oodera

Miscogaster cyzicus Walker, 1839 to Thinodytus

Mokrzeckia indica Rao, 1973 see Mokrzeckia orientalis, Mokrzeckia menzeli Neocatolaccus indicus Ayyar \& Mani, 1937 to Anisopteromalus

Neocatolaccus nupserhae Dutt \& Ferriere, 1931 to Oxysychus

Neoepisetnia coorgensis Narendran \& Sureshan, 1995 see Grooca coorgensis

Nigricolana megacephala (Waterston) to Toxeumorpha

Notoglyptus virescens Masi, 1917 - see Notoglyptus scutellaris

Oedaule stringifrons Waterston, 1922 to Dinarmus

Obtusiclava oryzae Rao, 1973 to Propicroscytus

Ophelosia crawfordi Riley, 1890 - see Ophelosia indica

Pachyceras xylophagorum Ratzeburg, 1844 to Roptrocerus
Pachyneuron pentatomivora Mani, 1939 - to Manineura

Pachyneuron uniarticulata Mani \& Saraswat, 1974 to Asaphes

Pachycrepoides arcotensis Mani \& Kurian, 1953 to Oricoruna

Pachycrepoides coorgensis Mani \& Kurian, 1953 to Oricoruna

Pachycrepoides indicus Bhatnagar, 1952 to Asaphes

Pachyneuron bakrotus Mani \& Saraswat, 1974 - see Pachyneuron groenlandicum

Pachyneuron karnalensis Mani, 1939 see Pachyneuron groenlandicum

Pachyneuron deccanensis Mani \& Saraswat, 1974 - see Pachyneuron aeneum

Pachyneuron ferriere Mani, 1939 - see Pachyneuron aphidis

Pachyneuron jandrighatensis Mani \& Saraswat, 1974 - see Pachyneruon chambaensis

Pachyneuron kamathi, Mani \& Saraswat, 1974 - see Pachyneuron aeneum

Pachyneuron karnalensis Mani, 1939 - see Pachyneuron groenlandicum

Pachyneuron lali Mani, 1939 - see Pachyneuron aphidis

Pachyneuron nazeeri Mani, 1939 to Euneura

Pachyneuron pentatomivora Mani, 1939 to Manineura

Pachyneuron triarticulata Mani \& Saraswat, 1974 - see Pachyneuron aphidids

Pachyneuron uniarticulata Mani \& Saraswat, 1974 to Asaphes

Picroscytus birmanus Masi, 1927 to Norbanus

Picroscytus indorum Masi, 1927 to Norbanus

Polycystus propinquus Waterston, 1915 to Halticoptera

Propicroscytus indicus Rao, 1981 - see Propicroscytus mirificus

Pteromalus groenlandicus Holmgren, 1872 to Pachyneuron

Pteromalus magniceps Walker, 1860 to Cephaleta

Pteromalus oryzae Cameron, 1881 to Anisopteromalus

Pteromalus schwenkei Roomi, Khan \& Khan, 1972 to Anisopteromalus

Roptrocerus sulcatus Waterston, 1922 - see Roptrocerus xylophagorum

Scutellista cyanea Motschulsky, 1859 - see Scutellista carulea

Sphaerakis maculatus Masi, 1924 to Dinarmus

Thaumasura indica Mani \& Kaul, 1973 - unplaced

Trichomalus apanteloctenus Crawford, 1911 to Trichomaopsis

Trigonogastra brunneicornis Ferriere, 1930 to Sphegigaster

Trigonogastrajoachimi Fernando, 1959

Trigonogastra megacephala Waterston, 1915 to Toxeumorpha.

Triogonogastra peninsularis Dubey, 1974 - unplaced

Trigonogastra rugosa Waterston, 1915 to Callitula

Zapachia beesoni Mani \& Kaul, 1973 to Metacolus 